\title{
Adoptively transferred Tregs accumulate in a site-specific manner and ameliorate signs of less advanced collagen-induced arthritis progress in rats
}

\begin{abstract}
Aim: The aim of the study was to assess the therapeutic effect and migration of adoptively transferred Tregs in the course of collagen-induced arthritis (CIA) in rats. Methods: Sorted $\mathrm{CD} 4{ }^{+} \mathrm{CD} 25^{+}$cells were cultured in the presence of 17- $\beta$-estradiol, stained with CellTracker and then administered into the articular capsule of ankle joint of animals in different stages of CIA progression. Results: Tregs diminished $\mathrm{CIA}$ signs only in animals with less advanced disease progress. Moreover, migration of transferred cells into the LN in the near proximity of the injection site and with distal location was almost completely stopped in animals with fully developed $\mathrm{ClA}$. Conclusion: Disease progression-related differences in migratory potential of in vitro induced Tregs may be responsible for the failure of cellular therapy during the advanced stages of CIA.
\end{abstract}

Keywords: adoptive transfer $\bullet$ collagen-induced arthritis $\bullet$ estrogen $\bullet$ foxp $3 \bullet$ regulatory T cells

Tregs play a crucial role in maintaining control over autoimmunity in the body. In both humans, and experimental animals (rats and mice), they represent $5-10 \%$ of the population of $\mathrm{CD}^{+}$cells [1]. In mice and rats, Tregs have a characteristic phenotype of $\mathrm{CD}_{4}{ }^{+} \mathrm{CD} 25^{+} \mathrm{FOXP} 3^{+}$. The main mechanism of suppressive Treg activity is based on the direct impact on the target cell [2]. T cells inhibit the activation and proliferation of autoimmunity-exhibiting lymphocytes by active suppression, in which the surface molecules such as GITR [3] and CTLA-4 [4] play an important role. Moreover, Treg lymphocytes survival and proliferation is dependent on the local presence of IL-2. Thus, constitutive expression of CD25 ( $\alpha$ chain of IL-2R) is one of hallmark of Treg population [5]. Mutations in the FOXP3 gene in both 'scurffy' mice and humans cause early symptoms of autoimmune diseases [6]. Retroviral FOXP3 gene transfer converts naive $T$ cells of the $\mathrm{CD}^{+}$phenotype into Tregs, whose phenotype is similar to the naturally occurring Tregs $\mathrm{CD}^{+}{ }^{+} \mathrm{CD} 25^{+} \mathrm{FOXP} 3^{+}$. This is why the
FOXP3 regulatory gene plays a crucial role in the development of regulatory cells [7].

However, the first attempts at intravenous injection of lymphocytes isolated from the spleens of normal DBA/IJ mice in animals with induced collagen-induced arthritis (CIA) were made in the 1990s [8] when Sakaguchi and co-authors have shown that regulatory $\mathrm{T}$ lymphocytes are essential for the prevention of organ-specific autoimmune diseases [9].

Depletion of the $\mathrm{CD} 4{ }^{+} \mathrm{CD} 25^{+}$cells resulted in the development of gastritis and thyroiditis, as well as several other organ-specific autoimmune diseases [9]. Similarly, depletion of $\mathrm{CD} 25^{+}$cells enhanced the exacerbation of peri-articular inflammation in the course of CIA. Furthermore, the adoptive transfer of $\mathrm{CD} 4^{+} \mathrm{CD} 25^{+}$cells to $\mathrm{DBA} / 1$ mice in an early inflammatory phase of CIA alleviated clinical presentation of the disease [10]. Also, in mice with model experimental autoimmune encephalomyelitis (EAE) and in non-obese diabetic mice the disease symptoms were successfully decreased after adoptive transfer of Tregs $\left(\mathrm{CD}^{+}{ }^{+} \mathrm{CD} 25^{+} \mathrm{FOXP}^{+}\right)$cells $[11,12]$.
Isaura Felcenloben*,1, Tomasz Piasecki², Julia Miller ${ }^{1}$, Joanna Rossowska ${ }^{3}$, Edyta Bańcyr', Wojciech Atamaniuk ${ }^{4}$, Marcin Nowak ${ }^{4}$, Jerzy Świerkot ${ }^{5}$, Kornel Ratajczak ${ }^{6}$ \& Anna Chełmońska-Soyta ${ }^{1,3}$

'Wroclaw University of Environmental \& Life Science, Faculty of Veterinary Medicine, Department of Immunology, Pathophysiology \& Prevention Veterinary, Norwida 31, 50-375 Wroclaw, Poland ${ }^{2}$ Wroclaw University of Environmental \& Life Science, Faculty of Veterinary Medicine, Department of Epizootiology \& Clinic of Birds \& Exotic Animals, Grunwaldzki 45, 50-366 Wroclaw, Poland

${ }^{3}$ Ludwik Hirszfeld Institute of Immunology \& Experimental Therapy Polish Academy of Sciences, Rudolfa Weigla 12, 53-114 Wroclaw, Poland ${ }^{4}$ Wroclaw University of Environmental \& Life Science, Faculty of Veterinary Medicine, Department of Pathology, Norwida 31, 50-375 Wroclaw, Poland ${ }^{5}$ Wroclaw Medical University, Faculty of Medicine, Department \& Clinic of Rheumatology \& Internal Medicine, Borowska 213, 50-556 Wroclaw, Poland ${ }^{6}$ Poznan University of Life Sciences; Veterinary Institute, Wolynska 35, 60-637 Poznan, Poland *Author for correspondence: isaura.felcenloben@up.wroc.pl

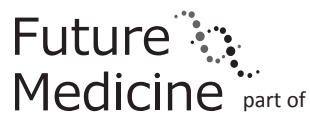


Sex hormones are a group of biologically active compounds, which play an important role, not only in reproduction, but also in the process of acquisition of immunological tolerance to self-antigens in autoimmune diseases [13], and in the maintenance of tolerance to the alloantigens during pregnancy [14]. Estrogens are produced by ovaries, placenta and adipose tissue [15], and physiologically they are able to induce the induced Treg (iTreg) cells [14]. Moreover, the function of estrogen-converted $\mathrm{CD} 4{ }^{+} \mathrm{CD} 25^{+} \mathrm{T}$ cells is similar to that of naturally occurring iTreg cells [16].

Therefore, estrogens may be recognized as natural inducers of Tregs. They may be used for the induction of iTregs under in vitro conditions for potential application during cell therapies. Such approach is different from pharmacological induction of $\mathrm{CD} 4{ }^{+} \mathrm{CD} 25$ - cells conversion into Tregs by rapamycin [17] or even by alltrans retinoic acid (ATRA), which is locally produced in Peyer's patches (PP) $[18,19]$.

The mechanisms by which estrogens induce Tregs are not well known. Tamoxifen, as a selective estrogen receptor modulator, is able to increase the number of mouse splenic Tregs, both in healthy animals and those suffering from autoimmune orchitis [20]. On the other hand, fulvestrant, which is a selective estrogen receptor down-regulator, inhibited estrogen-induced conversion of $\mathrm{CD} 4^{+} \mathrm{CD} 25^{-} \mathrm{T}$ cells into $\mathrm{CD} 4^{+} \mathrm{CD} 25^{+}$ Treg cells in in vitro experiments [16]. This suggests that nuclear estrogen receptors may, similarly to retinoic acid receptors (RAR or RXR), be involved in the induction of Tregs in mice [21]. Successful attempts of in vitro propagation of iTregs by estrogens with physiological doses of estrogens [22] supported such hypothesis. Up to date, however, there are no experimental data on the presence of estrogen response element sequences in promoter or conserved non-DNA coding sequences (CNS) regions of the FOXP3 gene.

Adoptive transfer of the $\mathrm{CD}^{+}{ }^{+} \mathrm{FOXP} 3^{+}$cells isolated from cervical, skin or gut lymph nodes, transferred by retro-orbital injection in mice, has shown that cervical lymph nodes donor Tregs were accumulated sitespecifically [23]. Moreover, it was proved that diseasespecific Tregs from draining lymph nodes were 15-50 times more efficient in suppressing autoimmune diseases of the ovaries, prostate and lacrimal gland, than those from nondraining lymph nodes [24]. Migration of Tregs, similarly to other lymphocytes, is directed by the chemokine system and the expression of adhesion molecules and their receptors.

Iwata $e t a l$. have proved that the migration of Tregs into the small intestine (SI), PP and mesenteric lymph nodes $(\mathrm{MN})$ is possible only after their induction from the naive $\mathrm{CD}^{+} \mathrm{T}$ cells in the presence of ATRA in an in vitro cell culture. Moreover, induction of the CCR9 chemokine receptor and the expression of integrin $\alpha 4 \beta 7$ by ATRA allows the migration to SI, PP and MN [25]. Unfortunately, a fate of Tregs adaptively administered into inflamed tissue is not well recognized.

Given the above reports of potential therapeutic determinants of Tregs in autoimmune phenomena, we have undertaken this study to examine the therapeutic effectiveness and migratory potential of adoptively transferred, estradiol-induced Tregs (aTregs) in female Wistar rats with early and full development stage of collagen induced arthritis.

\section{Methods}

Animals

Sixteen female, 6-week-old, inbred Wistar rats weighing 150-200 g from a colony bred at Wroclaw Medical University, Department of Pathology, Poland, were used. The experiment was conducted by permission No. 60/2011 of the Local Ethical Committee II in Wroclaw (Poland). The animals received water and maintenance food ad libitum, and were kept at room temperature $\left(24^{\circ} \mathrm{C}\right)$ in an animal facility at standard microbiological dark-lightn in a dark-light cycle (12:12).

\section{Model of $\mathrm{CIA}$}

Eight experimental animals were immunized twice, subcutaneously at the tail base with 1:1 (v/v) $200 \mu \mathrm{g}$ bovine CII (BD Bioscience, USA) and IFA (Freund's Incomplete Adjuvant; Sigma Aldrich, USA), at a volume of $200 \mu \mathrm{l}$ at a 7 -day interval. Seven to eight days after the second immunization, peri-articular swelling of hind paws was observed in four rats and these animals were qualified to group FD (fully developed CIA). The remaining four rats presented soft swelling of the hind paws and were assigned to the ES group (early stage of CIA). Group H consisted of four intact and healthy control animals. The rats were euthanized by inhalational anesthesia with isoflurane and dislocation of the cervical vertebrae. Rats from groups FD, ES and $\mathrm{H}$ (healthy rats) were euthanized 2 weeks after the adoptive transfer of in vitro propagated Treg cells. Lymphocytes for the adoptive transfer were isolated from the spleens of four healthy rats euthanized for this purpose.

\section{Clinical assessment of CIA}

The evaluation of arthritis severity was restricted to the hind paws of the animals, in accordance with the modified and extended numerical scale described by Suszko and Obminska-Mrukowicz [26]. The severity of clinical signs was scored as follows: 0 points - no change; $0-20$ points - swelling of the fingers $(0-4$ points for each of five fingers); $0-5$ points - redness and swelling of the ankle; $0-5$ points - redness and swelling in the 
paw; 0-10 points - severe, extensive inflammation of the hind paw multiple joints involved and/or deformation of joints (ankylosis) with function impairment. The arthritis score for each rat was the average score of both hind paws (the highest score for one hind paw of a rat $=40)$. According to the scoring pattern presented above, rats from group ES scored below or equal to 20 points and the score of the animals from group FD spanned over 20 points.

\section{ELISA test}

The level of anti-bovine collagen type II (anti-CII) IgG antibodies in the sera obtained from immunized and control rats was examined using an ELISA assay. Nunc Maxisorp plates were coated with $2 \mu \mathrm{g} / \mathrm{ml}$ bovine collagen (BD Bioscience, USA) in $0.1 \mathrm{M}$ carbonate buffer, $\mathrm{pH} 9.6$, by overnight incubation at $4^{\circ} \mathrm{C}$. The analyzed serum was diluted 500-fold in phosphatebuffered saline (PBS) buffer with $0.05 \%$ Tween 20 and incubated at $37^{\circ} \mathrm{C}$ for $1.5 \mathrm{~h}$. Anti-rat IgG (Jackson ImmunoResearch, USA) conjugated with horseradish peroxidase was used to assess the level of anti-CII antibodies. Supersensitive 3,3',5,5'-tetramethylbenzidine reagent (Sigma-Aldrich, USA) was used as substrate $(100 \mu \mathrm{l} /$ well). Enzymatic reaction was stopped after $15 \mathrm{~min}$ with $2 \mathrm{M} \mathrm{H}_{2} \mathrm{SO}_{4}(50 \mathrm{ml} /$ well $)$. The optical density of the wells' content was determined at $\lambda=450 \mathrm{~nm}$ using a BioTek $\mu$ Quantum reader (BioTek, USA).

\section{Flow cytometry}

Lymphocytes were isolated from the spleen and lymph nodes by sieving into PBS. After that, $1 \times 10^{6}$ lymphocytes were suspended in a FACS buffer $(40 \mathrm{ml}$ PBS, $0.8 \mathrm{ml}$ fetal calf serum [FCS; Life Technologies, USA], $40 \mathrm{mg} \mathrm{NaN}_{2}$ ). Cells were stained with anti ratCD4 FITC (e-Bioscience, USA) and anti-rat CD25-PE (e-Bioscience) for $30 \mathrm{~min}$ at $4^{\circ} \mathrm{C}$, washed twice with FACS buffer, fixed and permeabilized with Fix/Perm buffer (e-Bioscience) and permeabilization buffer (e-Bioscence) in accordance with the manufacturer's instructions. FOXP3 protein was stained with anti-Mouse/ Rat FOXP3 Alexa Fluor 647 (e-Bioscience) for $30 \mathrm{~min}$ at $4^{\circ} \mathrm{C}$. The cells were washed twice with FACS buffer, fixed in 2\% paraformaldehyde and analyzed using a FACSCalibur flow cytometer and Weasel 2.0 software.

\section{FACS sorting}

Lymphocytes isolated from the spleen and the lymph nodes of donor rats were mixed together and suspended in PBS $+2 \%$ FCS and stained with rat antiCD4 FITC (e-Bioscience), anti-rat CD25-PE (e-Bioscience) for $30 \mathrm{~min}$ at $4^{\circ} \mathrm{C}$. The cells were then washed twice with PBS $+2 \%$ FCS, and disaggregated in sterile FACS tubes with a $35-\mu \mathrm{m}$ nylon mesh cell strainer cap
(BD Biosciences, USA). A total of $50 \times 10^{6}$ cells prepared in this manner were sorted on the BD FACSAria II at a speed of 15,000 cells/s. Following sorting, the $\mathrm{CD} 4{ }^{+} \mathrm{CD} 25^{+}$cells were immediately centrifuged in PBS + 2\% FCS. Then, cell viability was determined by trypan blue exclusion (Sigma Aldrich) and the cells were transferred to the culture medium.

\section{Culture of $\mathrm{CD} 4{ }^{+} \mathrm{CD} 25^{+}$cells}

After sorting, the cells were cultured at $1 \times 10^{6}$ cells/well, in 24-well plates coated with $10 \mu \mathrm{g} / \mathrm{ml}$ anti-CD3 and $1 \mu \mathrm{g} / \mathrm{ml}$ anti-CD28 in the presence of $100 \mathrm{U} / \mathrm{ml}$ IL-2 in RPMI 1640 medium supplemented with 100 unit $/ \mathrm{ml}$ penicillin/streptomycin, $20 \mathrm{mM}$ L-glutamine, $5 \mathrm{ng} / \mathrm{ml}$ TGF- $\beta, 10 \%$ FCS and 5 or $10 \mathrm{ng} / \mathrm{ml}$ of $17-\beta$-estradiol (Sigma Aldrich, USA). Dosage of $17-\beta$-estradiol was tested according to data from the literature $[16,22]$. Based on these tests, two doses were selected: 5 and $10 \mathrm{ng} / \mathrm{ml}$. The cells were cultured at $37^{\circ} \mathrm{C}$ and in $5 \% \mathrm{CO}_{2}$ for 4 days, phenotyped to assess a purity of the obtained $\mathrm{CD} 4^{+} \mathrm{CD} 25^{+} \mathrm{FOXP} 3^{+}$cells by flow cytometry, as described above.

\section{Staining the Tregs with CellTracker}

Following culture with estrogen, $4 \times 10^{6}$ $\mathrm{CD}^{+}{ }^{+} \mathrm{CD} 25^{+} \mathrm{FOXP}^{+}$cells were stained with CellTracker $^{\text {TM }}$ Green CMFDA (Life Technologies) in accordance with the manufacturer's protocol. The cells were then washed with PBS buffer, mixed with CellTracker to a final working concentration of $25 \mu \mathrm{M}$ and incubated for $30 \mathrm{~min}$ at $37^{\circ} \mathrm{C}$ and in $5 \% \mathrm{CO}_{2}$, washed with PBS twice and suspended in PBS.

\section{Adoptive transfer}

A total of $0.2 \times 10^{6}$ cells stained with CellTracker ${ }^{\mathrm{TM}}$ Green CMFDA were suspended in $100 \mu \mathrm{l}$ of PBS buffer and injected into the articular capsule of the ankle joint of the rat's right paw on the 21st day after the first immunization with CII and IFA. Rats were anesthetized using a volatile agent - they were placed in a rodent anesthetic chamber, which was filled rapidly with a high concentration of halothane vapor ( $3 \%$ vol.) with oxygen as carrier gas. Instantly after the loss of consciousness, rats were removed from the chamber and intra-articular injection was performed with the control of a finger. Cells were injected when the needle reached the space under the ankle capsule. Healthy, intact rats were used as the control group. Two weeks after the injection, the cells were analyzed using a FACSCalibur flow cytometer and Weasel 2.0 software.

\section{Tissue material}

Peripheral blood for serological examination was collected from the heart of the anesthetized animals before 
euthanasia. Spleen (SPL), popliteal (PN), mesenteric (MN), inguinal (IN) and axillary lymph nodes (AXN) were dissected from euthanized animals. Then, hind paws were dissected and fixed in buffered $4 \%$ formalin in PBS.

\section{X-rays}

X-ray examination was performed before adaptive transfer and after euthanasia of rats using a Gierth HF 90/20 x-ray unit and conventional x-ray film (Aqua Mamoray HD). Each animal underwent examination of both distal hind limbs in a dorso-plantar plane. The following radiographic abnormalities were considered: $\mathrm{a}$ - soft tissue swelling; $\mathrm{b}$ - narrowing/widening of joint space; $\mathrm{c}-$ subchondral bone erosions according to modified Larsen classification: 0 - normal; 1 - distinct focal osteolysis in some joint areas; 2 - well visible osteolysis in some joint areas; 3 - total bone erosion in a joint area, $\mathrm{D}$ - joint degeneration, $\mathrm{N}$ - normal ankle joint.

\section{Histology}

Formalin-fixed sections of joints were embedded in paraffin blocks, sliced and stained with Delafield's hematoxylin --Water eosin. Preparations were viewed and evaluated using a BX53 Olympus microscope. Digital photos were taken with an Olympus Colorview IIIu camera.

\section{Statistical analysis}

Research was done in one experiment and there were four rats in every group constituting an independent experimental system. Results were analyzed using the Statistica software, version 10.0, by analysis of variance and Duncan's post-hoc test for statistical significance, with significance levels of $\mathrm{p}<0.05$ and $\mathrm{p}<0.01$.

\section{Results}

\section{aTREG culture with estrogen}

Sorted $\mathrm{CD} 4{ }^{+} \mathrm{CD} 25^{+}$cells were cultured in media with two different concentrations of $17-\beta$-estradiol: 5 and $10 \mathrm{ng} / \mathrm{ml}$. There were no significant differences in the survival rate between cultures with $5 \mathrm{ng} / \mathrm{ml}$ and those with $10 \mathrm{ng} / \mathrm{ml}$ (data not shown). However, expression of FOXP3 was higher in cells cultured with $10 \mathrm{ng} / \mathrm{ml}$ $(89.06 \pm 4.22$ vs $78.57 \pm 2.78$, data not shown). In control culture without $17-\beta$-estradiol, there was a $58.62 \%$ frequency of $\mathrm{CD}_{4}{ }^{+} \mathrm{CD} 25^{+} \mathrm{FOXP} 3^{+}$cells. Therefore, further analysis and adoptive transfer were performed with cells stimulated with estradiol at a concentration of $10 \mathrm{ng} / \mathrm{ml}$ (Figure 1C).

$\mathrm{CD} 4{ }^{+} \mathrm{CD} 25^{+}$cells were isolated from the spleens and lymph nodes of four healthy rats, and sorted using a FACS sorter with an average purity $92.9 \pm 1.37 \%$
(Figure 1A). Then the $\mathrm{CD} 4{ }^{+} \mathrm{CD} 25^{+}$cells were cultured for 4 days with $10 \mathrm{ng} / \mathrm{ml} 17-\beta$-estradiol and the expression of $\mathrm{FOXP}^{+}$cells was observed in $96.2 \pm 3.1 \%$ of cells (Figure 1B).

\section{Adoptive transfer of aTREGS}

Eight rats were immunized twice with intradermal injections of $200 \mu \mathrm{g}$ of bovine CII into the base of the tail (groups ES and FD). Then, the animals were observed and the development of disease was scored. Three weeks after the second immunization, four rats displayed full symptomatic CIA (group FD) and the other four rats showed less advanced signs of CIA (group ES; Figure 2A).

Healthy rats (group $\mathrm{H}$ ) and rats with CIA (groups ES and FD) had the prepared aTregs in PBS adoptively transferred. The adoptive transfer in rats with fully developed CIA (group FD) did not change the score of the disease, neither in the cell-injected paws, nor in the control paws. In contrast, in rats with the less pronounced disease (group ES), the adoptive transfer ameliorated the progress of CIA in cell-injected paws (Figure 2B). In addition, we compared the left and right back limbs on day 0,7 and 14 after the adoptive transfer. On day 14 , only rats with early stage of CIA had significant differences; the left hind limb was scored $25 \pm 11$ points on the symptom scale, versus the right hind limb, which was scored $10 \pm 5$ points on the symptom scale (Figure 2C). No significant differences between left and right hind limbs were observed in rats with fully developed CIA during the whole time of observation after the adoptive transfer (Figure 2D).

However, in aTreg + PBS injected paws of both ES and FD groups, signs of disease were present until the end of the observation period (Figure 2B) for 2 weeks. The animals were then euthanized.

Although differences between groups ES and FD in the progress of the disease were observed, the level of anti-CII antibodies was not significantly different. The level of anti-CII antibodies was measured on the 14th day after the adoptive transfer (Figure 3).

In rats from group $\mathrm{ES}$, radiographic examination performed before the adoptive transfer revealed light swelling of the soft tissues. On the other hand, 2 weeks after the adoptive transfer in control paws (without cell injection), widening/narrowing of the joint space and slight osteolysis were observed in addition to soft tissue swelling around the joint. However, $\mathrm{x}$-ray examination revealed no visible changes in paws with transferred cells (Figure $4 \mathrm{~A}-\mathrm{F}$ ). In rats from group $\mathrm{FD}$, prior to adoptive transfer, severe swelling of soft tissues around the joint and widening/narrowing of the joint space were observed, indicating strong osteolysis and joint degeneration. Two weeks after the adoptive transfer, no 

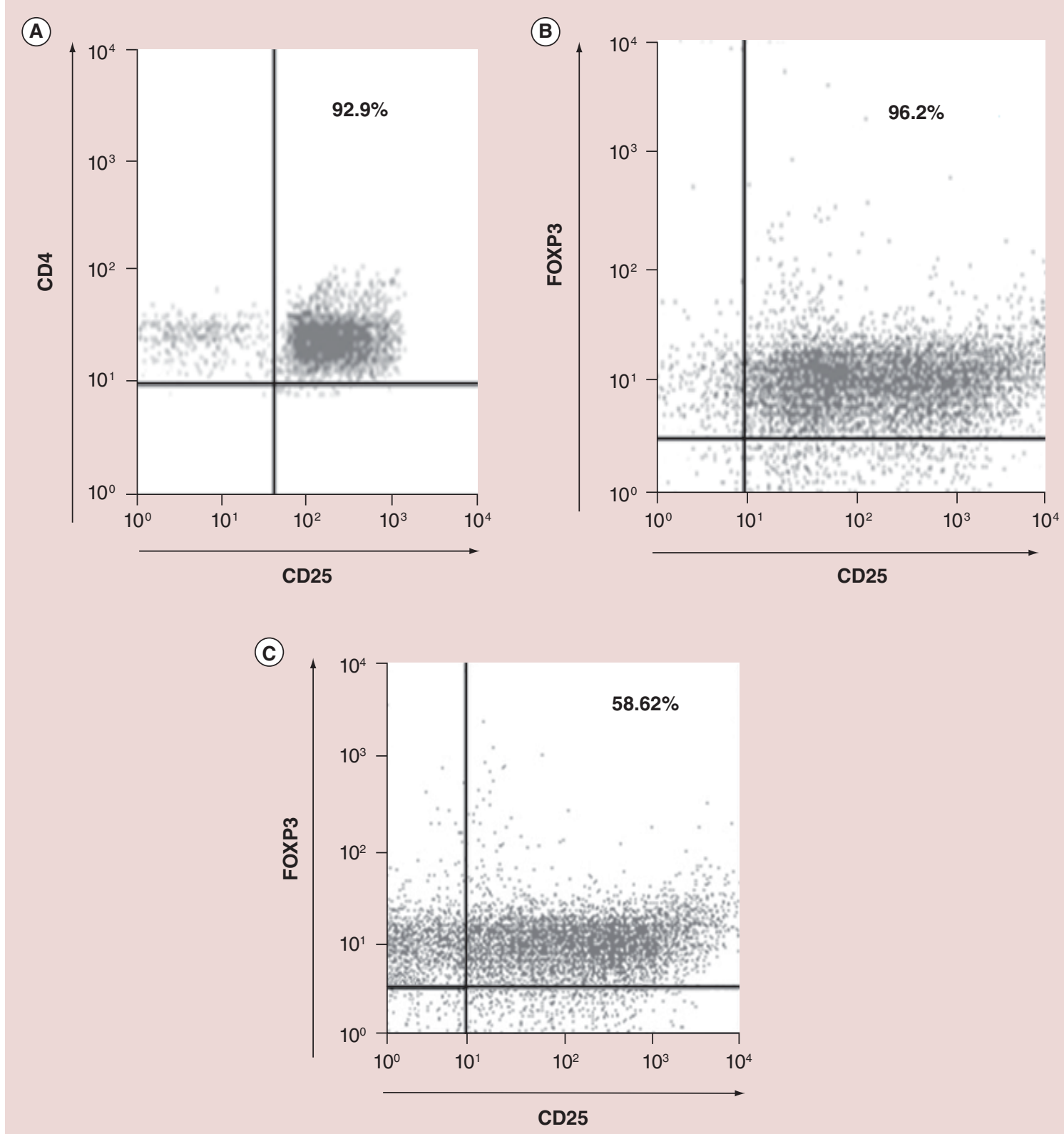

Figure 1. Purity of cells. (A) The purity of iTregs after cell sorting. (B) Purity of $C D 4+C D 25+F O X P 3^{+}$cells after cell culture with $10 \mathrm{ng} / \mathrm{ml} 17-\beta$-estradiol. (C) Purity of CD4+CD25+FOXP3+ cells after cell culture without $10 \mathrm{ng} / \mathrm{ml}$ 17- $\beta$-estradiol (control culture).

significant improvement was observed in these animals in $\mathrm{X}$-ray examination (Figure 4A-F \& Table 1).

After the adoptive transfer, microscopic examination of ankle joints of hind paws of rats with minor early symptoms of CIA revealed inflammatory infiltration of single cells, predominantly lymphocytic, within the synovium. In contrast, in animals with severe CIA, massive inflammatory infiltrates of mononuclear cells, mainly lymphocytes (including plasma cells and macrophages), within the synovial membrane were observed (Figure 4I \& II). Moreover, hypertrophy of the ependymal layer (synoviocytes), focal untangled villi fibrin deposits, local severe microvascular proliferation in some areas penetrating the inflamed bone tissue were noted (Figure 4III). Also, extensive swelling and lymphocytic infiltrations within the peri-articular tissue were observed (Figure 4IV). The histopathological pattern of normal synovial membrane has shown a thin intima comprised of one layer of synoviocytes; subintima contained a loose connective tissue and few blood vessels, with no inflammatory infiltrates (Figure 4V). Massively thickened synovial membrane with severe inflammatory infiltrates included mainly lymphocytic cells, few plasmocytic cells and macro- 


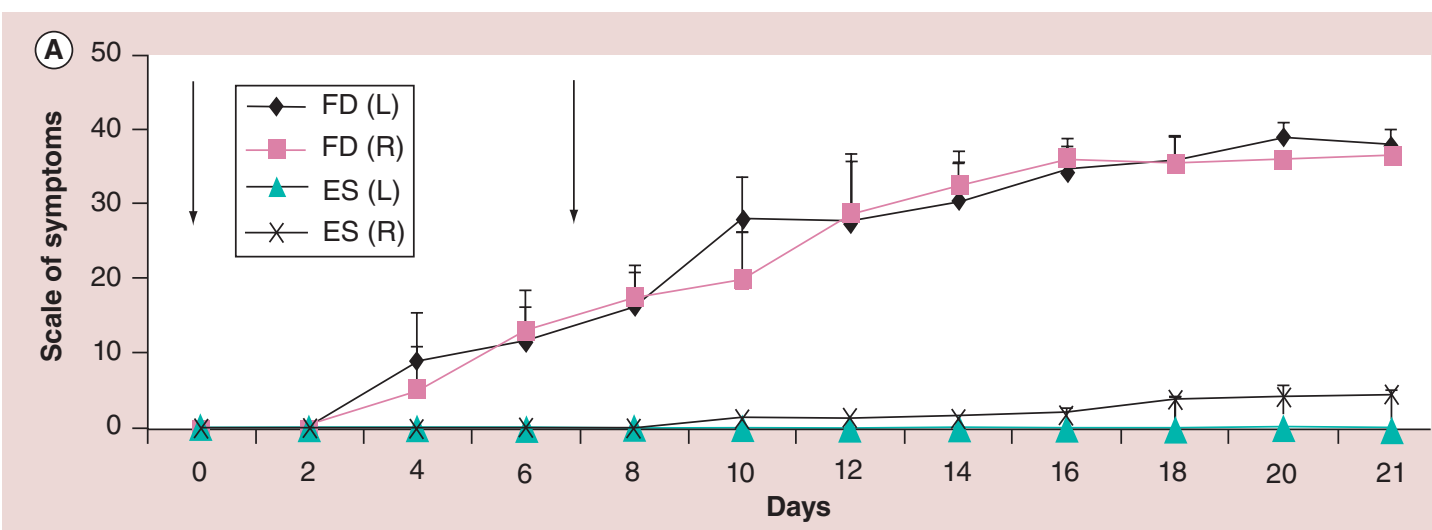

(B)

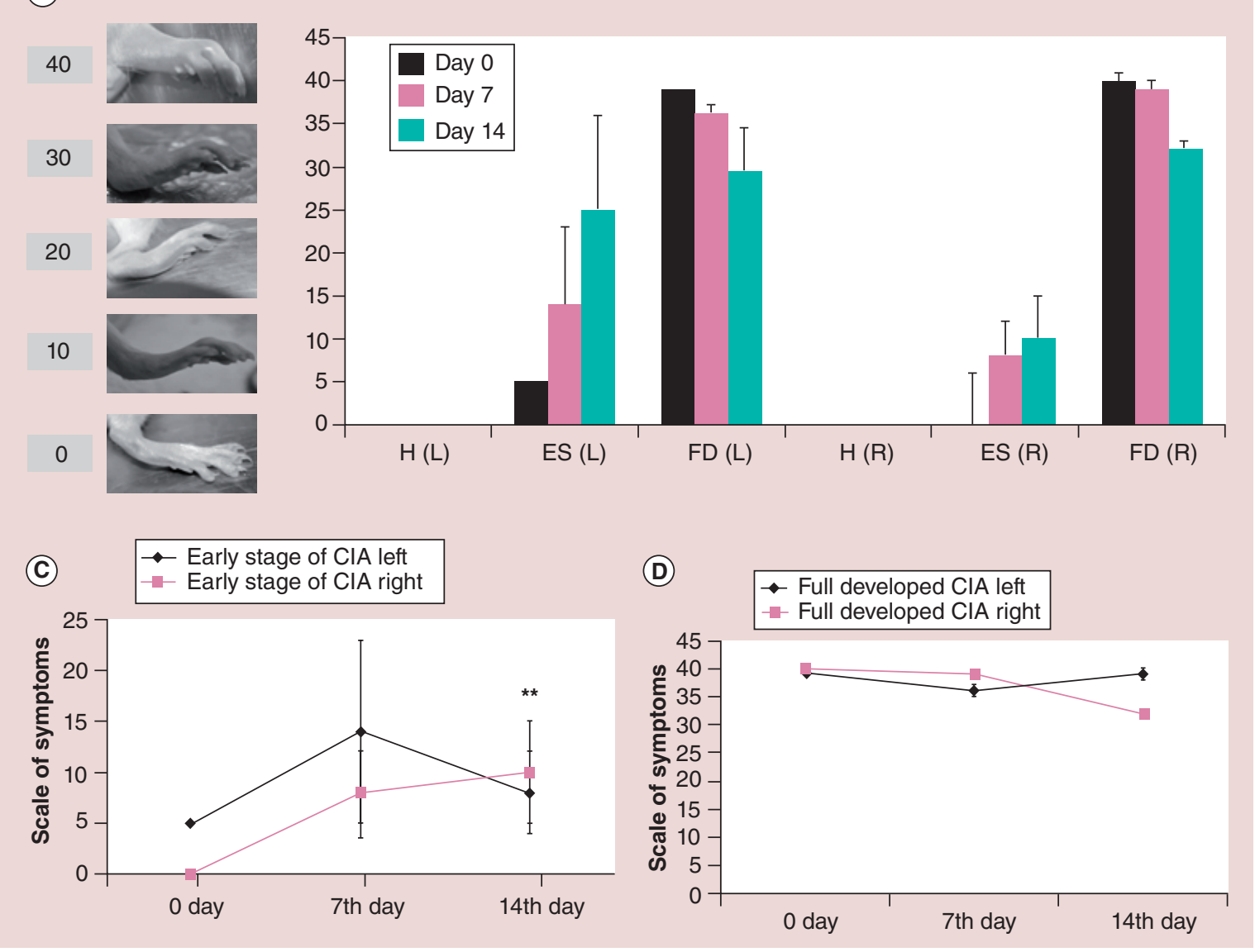

Figure 2. Development of symptoms of collagen-induced arthritis. (A) Development of CIA symptoms before adoptive transfer in rats from groups ES and FD according to CIA symptom score ES (L), ES (R), FD (L) and FD (R). Rats from the group $\mathrm{H}$ did not show any symptoms of the disease (data not shown). Arrows indicate days on which the rats were immunized. (B) Comparison of CIA symptoms in rats after the adoptive transfer of induced Tregs into right hind ankle in healthy rats (group H), rats with FD CIA (group FD) and in rats with ES CIA (group ES). (C) Comparison of change of CIA symptoms between left and right hind limb on days 0, 7 and 14 after the adoptive transfer of $\mathrm{CIA}$ in rats from ES group. (D) Comparison of change of $\mathrm{CIA}$ symptoms between left and right hind limb on day 0, 7 and 14 after adoptive transfer of $\mathrm{CIA}$ in rats from FD group. The severity of clinical signs was scored as follows: 0 point - no change; $0-20$ points - swelling of the fingers ( $0-4$ points for each of five fingers); 0-5 points - redness and swelling of the ankle; $0-5$ points - redness and swelling of the paw; 0-10 points - severe, extensive inflammation of the hind paw with multiple joints involved and/or deformation of joints (ankylosis) and function impairment. The arthritis score for each rat was the average of the scores of both hind paws (the highest score for one hind paw of rat $=40) . n=4$.

**Significant difference at $\mathrm{p}<0.01$.

CIA: Collagen-induced arthritis; ES: Early stage; FD: Fully developed; H: Control; L: Left paw; R: Right paw. 
phages; moreover, amplification of small blood vessels is visible (Figure $4 \mathrm{VI})$.

Due to the number of cells stained by CellTracker ${ }^{\mathrm{TM}}$ Green CMFDA observed on the cytograms being very low, the positively stained cells were counted from 50,000 populations of lymphocytes from lymphocytic gate in an forward-scattered light/side-scattered light system (data not shown).

CellTracker staining has shown that cells (aTregs) injected near the inflamed joint mainly traffic to the popliteal lymph nodes $(866 \pm 502$ cells in $\mathrm{H} ; 398 \pm 308$ cells in ES; $2 \pm 2$ cells in FD) and to the spleen $(1879 \pm 478$ cells in H; $2122 \pm 1903$ cells in ES; $2544 \pm 2849$ cells in FD; Figure 5). In other tissues, the frequency of CellTracker+ cells was lower. We have also found that the migration of adaptive Tregs in rats with CIA is different from that in healthy rats. In every sampled tissue, except for the spleen, it was observed that the frequency of adaptive Tregs was the highest in healthy rats. In rats with early-stage CIA, the adaptive Tregs migrated into the sampled tissues but to a lower extent than in healthy rats. Less intense migration of adaptive Tregs was observed in rats with fully developed CIA. It is worth noting that in all the examined groups, the frequency of adoptive Tregs that migrated into the spleen was comparable (Figure 5).

Statistically significant differences in the frequency of migrating were visible in the right popliteal lymph node $(866 \pm 502$ cells in healthy rats vs $2 \pm 1$ cells in rats with fully developed CIA, $\mathrm{p}<0.05$; Figure 5), in both inguinal lymph nodes (significant differences at $\mathrm{p}<0.01$ between healthy rats (group $\mathrm{H}$ ) and rats with fully developed CIA (group FD; Figure 5) and in both axillary lymph nodes (significant differences at $\mathrm{p}<0.01$ or $\mathrm{p}<0.05$ between healthy rats (group $\mathrm{H}$ ) and rats from groups ES and FD; Figure 5).

In contrast to the results of the aTregs that were tracked by CellTracker staining, the frequency of naturally induced iTregs was higher in rats with fully developed CIA than in rats with early-stage CIA or healthy rats. The frequency of iTregs in popliteal lymph nodes was significantly different at $\mathrm{p}<0.05$ in healthy rats (group H, $5.6 \pm 1.09 \%$ ) and in those with fully developed CIA (group FD, $7.81 \pm 0.96 \%$; Figure 6 ). In the right inguinal lymph nodes, the frequency of iTregs was significantly different at $\mathrm{p}<0.01$ in healthy rats (group $\mathrm{H}, 4.1 \pm 0.6 \%)$ and in those with fully developed CIA (group FD, $7.39 \pm 1.4 \%$; Figure 6).

These results reveal the differences between the traffic of aTregs and iTregs in the body in inflammatory and steady state conditions.

\section{Discussion}

Only a few papers report that estrogen is an inductor of proliferation and differentiation of $\mathrm{CD}^{+}$cells

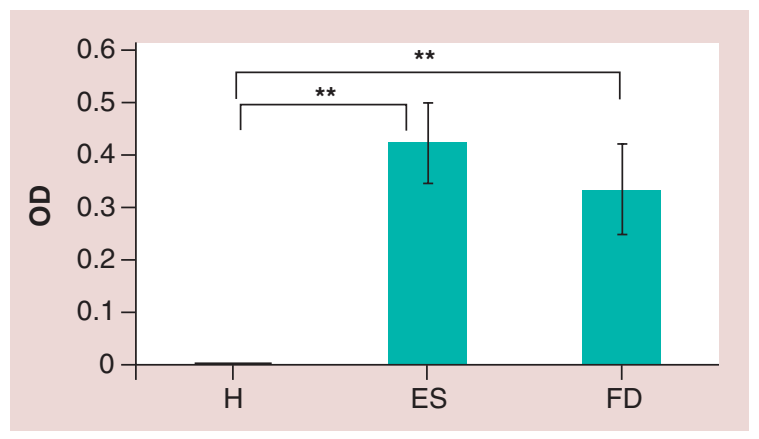

Figure 3. Level of anti-bovine collagen II antibodies on the 14th day after the adoptive transfer of Tregs in healthy control rats and in rats with ES and FD collagen-induced arthritis examined by ELISA. $n=4$. **Significant difference at $p<0.01$.

ES: Early stage; FD: Fully developed; H: Control; OD: Optical density.

into Tregs. Tai et al. (2008) reported that physiological levels of estrogen not only drove the expansion of $\mathrm{CD} 4{ }^{+} \mathrm{CD} 25^{+} \mathrm{T}$ cells, but also increased the level of FOXP3 mRNA and protein in vivo and in vitro [16]. They found that the culture of $\mathrm{CD} 4{ }^{+} \mathrm{CD} 25^{+}$cells with $0.2-1 \mathrm{ng} / \mathrm{ml}$ of $17-\beta$-estradiol (which corresponds to the estrogen level in the mouse uterus) increased the expression of FOXP3 at the protein level. However, pharmaceutical doses of estrogens (17- $\beta$-estradiol) used for expansion and differentiation of $\mathrm{CD} 4{ }^{+} \mathrm{CD} 25^{-}$ $\mathrm{T}$ cells into Treg cells were higher and spanned from 1 to $50 \mathrm{ng} / \mathrm{ml}[16,27]$. Based on the data presented above and our preliminary experiments, we chose the dose of $10 \mathrm{ng} / \mathrm{ml}$ as a stimulatory dose of $17-\beta$-estradiol for the propagation of aTregs. This concentration of estrogen increased the percentage of FOXP3-positive cells up to $96.2 \pm 3.1 \%$ of the sorted and cultured $\mathrm{CD}^{+} \mathrm{CD} 25^{+}$ lymphocytes. This conversion rate is similar to that of rapamycin [17] and it has confirmed the usefulness of 17-beta estrogen as a natural Treg inducer under in vitro conditions.

Next, we tested if estrogen-induced Treg could inhibit the development of CIA and regulate humoral specific response against bovine CII. In order to do that, we adoptively transferred Tregs into the right hind paws of rats with early stage or fully developed CIA, where healthy rats were used as the control group. In our experiment we confirmed the presence of specific anti-CII antibodies in the sera of immunized rats during a single inspection on the 14th day after adoptive transfer (21st day after the first immunization). In mice with CII-induced arthritis, the level of anti-CII decreased after the adoptive transfer of $\mathrm{CD}^{+}{ }^{+} \mathrm{CD} 25^{+} \mathrm{FOXP}^{+}$while reducing CIA lesions at the same time [28]. In our results we found that there were no significant differences in the level of anti-CII antibodies between groups ES (showing therapeutic 


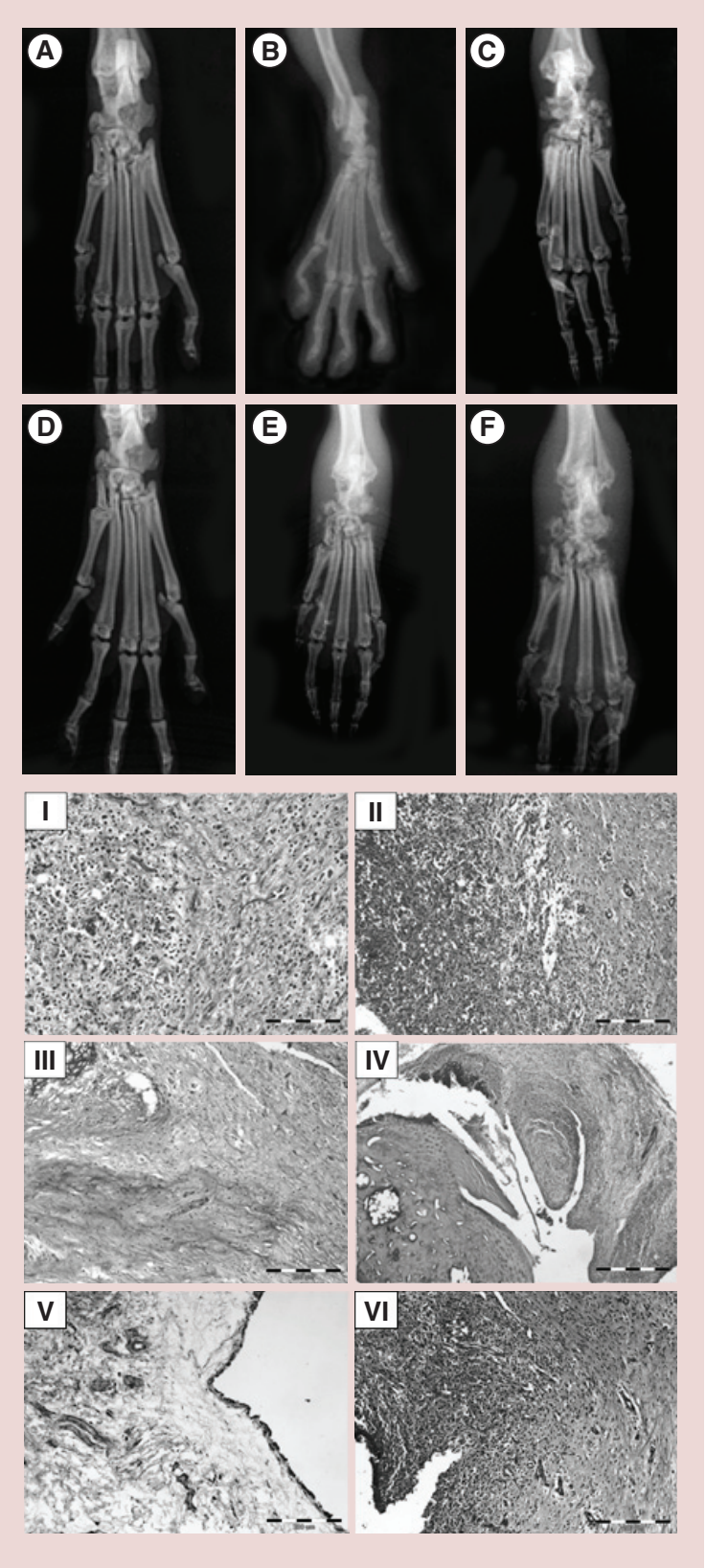

Figure 4. Symptoms of collagen-induced arthritis on x-ray and histological levels. (A-C) Representative $x$-ray images of joints from healthy rats before the adoptive transfer $(A)$ and rats suffering from collagen-induced arthritis (CIA; $[B]$ rat with earlystage $\mathrm{CIA} ;[\mathrm{C}]$ rat with fully developed $\mathrm{CIA}$ ). (D-F) Representative $x$-ray images of joints from healthy rats after the adoptive transfer (D) and rats suffering from $\mathrm{CIA}$ ([E] rat with early-stage $\mathrm{CIA}$; [F] rat with fully developed CIA). (I-IV) Histological analysis of joints in rats from the fully developed group: (I) massive inflammatory infiltrates (mainly lymphocytic cells) in the thickened synovium; (II) massive inflammatory infiltrates (mainly lymphocyte cells and the plasma isolated and macrophages) in the thickened synovium; (III) edema and lymphocytic infiltration in periarticular tissue;
Figure 4. Symptoms of collagen-induced arthritis on x-ray and histological levels (cont.).

(IV) inflammatory infiltrates in the thickened and swollen synovium. (V-VI) Histological analysis of joints in healthy rats (V) or with CIA rats (VI) with no adoptive transfer: (V) histopathological pattern of normal synovial membrane. A thin intima comprised of one layer of synoviocytes; subintima containing loose connective tissue and few blood vessels, without inflammatory infiltrates. (VI) Massively thickened synovial membrane with severe inflammatory infiltrates including mainly lymphocytic cells, few plasmocytic cells and macrophages; also, amplification of small blood vessels is visible.

effect of adoptive transfer of Tregs) and FD (with no therapeutic effect) 14 days after the adoptive transfer of Tregs. This discrepancy may be attributed to the fact that adoptively transferred cells in mice were clonally expanded in the presence of DC pulsed with CII. In contrast, in our experiments we used polyclonal activated $\mathrm{CD} 4{ }^{+} \mathrm{CD} 25^{+}$cells [28].

Significant therapeutic role of adoptively transferred Tregs was confirmed in a CIA model in mice [10,28-31]. It has been shown that the effect of adoptively transferred Treg-mediated treatment is dependent on the site of administration of the cells and the degree of disease progression.

Morgan et al. (2005) found that a single transfer of Tregs markedly slowed disease progression, which could not be attributed to the decreases in systemic levels of CII - specific T and B cell responses, since these remained unchanged after the adoptive transfer. However, Tregs could be found in the inflamed synovium soon after the transfer, indicating that regulation may occur locally in the joint [10]. In our studies, the cells were administered locally near the inflamed joints. Therapeutical effect was dependent on an individual response, but above all on the progression of the disease and the severity of inflammatory reaction in the joint. As demonstrated in the work of Komatsu et al., ongoing inflammatory conditions can differentiate iTreg into Th17 [32]. This is one of the probable reasons why local supply of Tregs to inflamed sites is not always effective.

Moreover, the efficiency of adoptive transfer in CIA depends on the time of application of the cells. It was observed when the cells were adoptively transferred before inducing the model disease [28] in the early stage of CIA [10] or in full development of CIA [30]. For this reason, in our study we evaluated the efficiency of adoptive transfer of Tregs in animals in different stages of CIA development, with ongoing inflammatory process, which simulates a clinical situation in humans.

In CIA, however, in contrast to rheumatoid arthritis (RA) [33], there is no clear distinction between early 
Table 1. Radiological analysis of joints in healthy and collagen-induced arthritis rats: (early stage of collagen-induced arthritis and fully developed collagen-induced arthritis) before and after adoptive transfer.

\begin{tabular}{|c|c|c|c|c|c|}
\hline \multirow[t]{2}{*}{ Group } & \multirow{2}{*}{$\begin{array}{l}\text { Rat } \\
\text { identification } \\
\text { number }\end{array}$} & \multicolumn{2}{|c|}{ Before adoptive transfer } & \multicolumn{2}{|c|}{ After adoptive transfer } \\
\hline & & $\begin{array}{l}\text { Transferred } \\
\text { paw }\end{array}$ & $\begin{array}{l}\text { Control } \\
\text { paw }\end{array}$ & $\begin{array}{l}\text { Transferred } \\
\text { paw (right) }\end{array}$ & $\begin{array}{l}\text { Control paw } \\
\text { (left) }\end{array}$ \\
\hline \multirow[t]{4}{*}{$\mathrm{H}$} & 1 & 0 & 0 & 0 & 0 \\
\hline & 2 & 0 & 0 & 0 & 0 \\
\hline & 3 & 0 & 0 & 0 & 0 \\
\hline & 4 & 0 & 0 & 0 & 0 \\
\hline \multirow[t]{4}{*}{ ES } & 5 & $a$ & 0 & 0 & $a b c 3 d$ \\
\hline & 6 & $a$ & $a$ & 0 & $a b c 1$ \\
\hline & 7 & $a$ & 0 & 0 & $a b c 1$ \\
\hline & 8 & $a$ & $\mathrm{a}$ & 0 & $a$ \\
\hline \multirow[t]{4}{*}{ FD } & 9 & 0 & $a$ & $a b c 3 d$ & $a$ \\
\hline & 10 & $a b c 2 d$ & abc1d & abc1d & $a b c 3 d$ \\
\hline & 11 & $a b c 3 d$ & $a b c 2 d$ & 0 & $\mathrm{c} 1$ \\
\hline & 12 & 0 & $a b c 3 d$ & abc1d & $a b c 2 d$ \\
\hline
\end{tabular}

and full development of the disease. In this study, the early stage of CIA in rats was determined when the score of macroscopic signs of the disease did not exceed 20 points in the algorithm used to assess the progress of the disease, and additional histological examination revealed lack of erosive changes in bone histology. In contrast, full development of CIA was assessed when the score of macroscopic signs exceeded 20 points and the histological picture confirmed erosive destruction of the bone.

Such classification enabled us to compare the effects of locally administered $\mathrm{CD} 4{ }^{+} \mathrm{CD} 25^{+} \mathrm{FOXP} 3^{+}$ cells on the progression of the disease related to the degree of the inflammatory response.

Ohata and colleagues observed a decrease in CIA symptoms in DBA1/J mice treated with adoptive transfer of Tregs given prior immunization. However, if adoptive transfer of the same number of Tregs was performed after the booster immunization, when CIA was developed, it did not cause any decrease in CIA symptoms, which indicated progressive development of resistance to suppression by Tregs [28].

Similarly to the data presented above, in our experiments, the adoptive transfer of Tregs in rats with fully developed CIA did not improve the course of the disease. However, it is worth noting that in the group of rats with an early stage of CIA, disease progression was diminished, which was apparent in both the disease score and the x-ray image.
Therefore, our observations indicate that local severe inflammatory conditions are a contraindication for adoptive transfer of Tregs.

To examine how the effectiveness of adoptive transfer may depend on the presence and migration of aTregs into different compartments of the body, we observed the frequency of iTregs and adoptively transferred aTregs. Therefore, the adoptively transferred aTregs were stained with CellTracker, and iTregs $\left(\mathrm{CD} 4^{+} \mathrm{CD} 25^{+} \mathrm{FOXP}^{+}\right)$were identified by FACS using labeled antibodies.

It is not known if estrogen-induced iTregs have better migratory properties than other iTregs. There are only limited data available regarding estrogen-mediated T-cell migration. It has been shown that estrogens inhibit T-cell migration into the central nervous system tissue, by exerting neuroprotective effect, which promote axon and myelin survival. Moreover, they inhibit the migration of inflammatory cells into the CNS, reducing production of numerous cytokines, chemokines and chemokine receptors within the CNS [34]. Overall, the effects of E2 on EAE involve immune regulation, inhibition of cell migration and CNS neuroprotection [35]. Our observations indicate that estrogen-induced Tregs maintain their migratory capacity, as we have found the adoptively transferred cells in peripheral lymph nodes and in the spleen of healthy rats and animals with CIA. However, they differ in their migratory potency between healthy rats, 

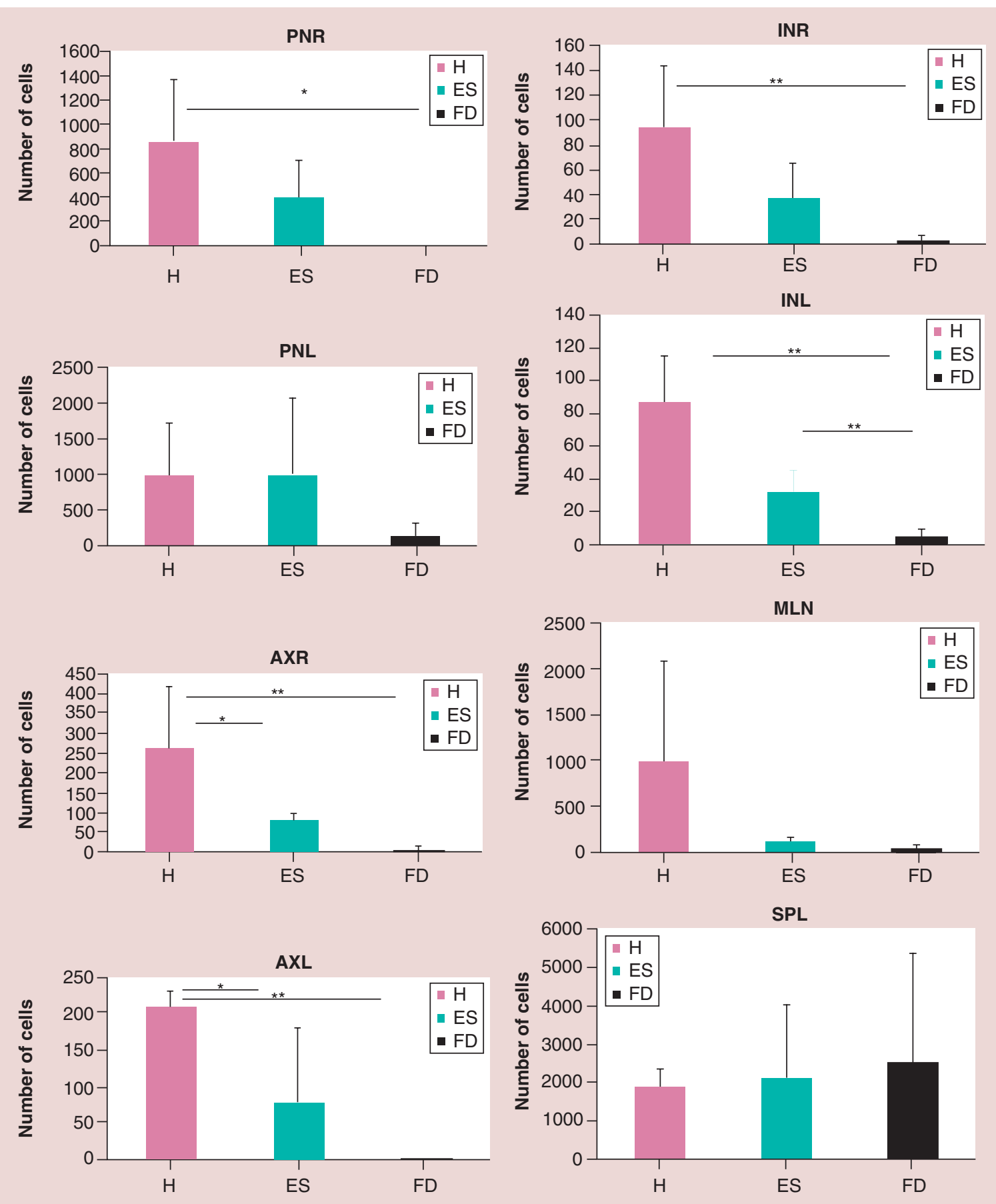

Figure 5. Migration of $\mathrm{CD} 4{ }^{+} \mathrm{CD} 25^{+}$cells from adoptive transfer in healthy Wistar rats, rats at an early-stage of collagen-induced arthritis (early stage group) and in rats with fully developed collagen-induced arthritis (fully developed group). $n=4 . C D 4+C D 25+$ cells were stained with CellTracker Green.

* Significant difference at $p<0.05$.

**Significant difference at $p<0.01$.

AXL: Left axillary lymph nodes; AXR: Right axillary lymph nodes; ES: Early stage; FD: Fully developed; H: Control; INL: Left inguinal lymph nodes; INR: Right inguinal lymph nodes; MLN: Mesenteric lymph nodes; PNL: Left popliteal lymph nodes; PNR: Right popliteal lymph nodes; SPL: Spleen.

animals with fully developed and those in early phase of the disease. We found that administration by adoptive transfer of induced in vitro Tregs from healthy donors to healthy animals induced their migration into popliteal, inguinal and axillary lymph nodes, but during the development of CIA, the frequency 

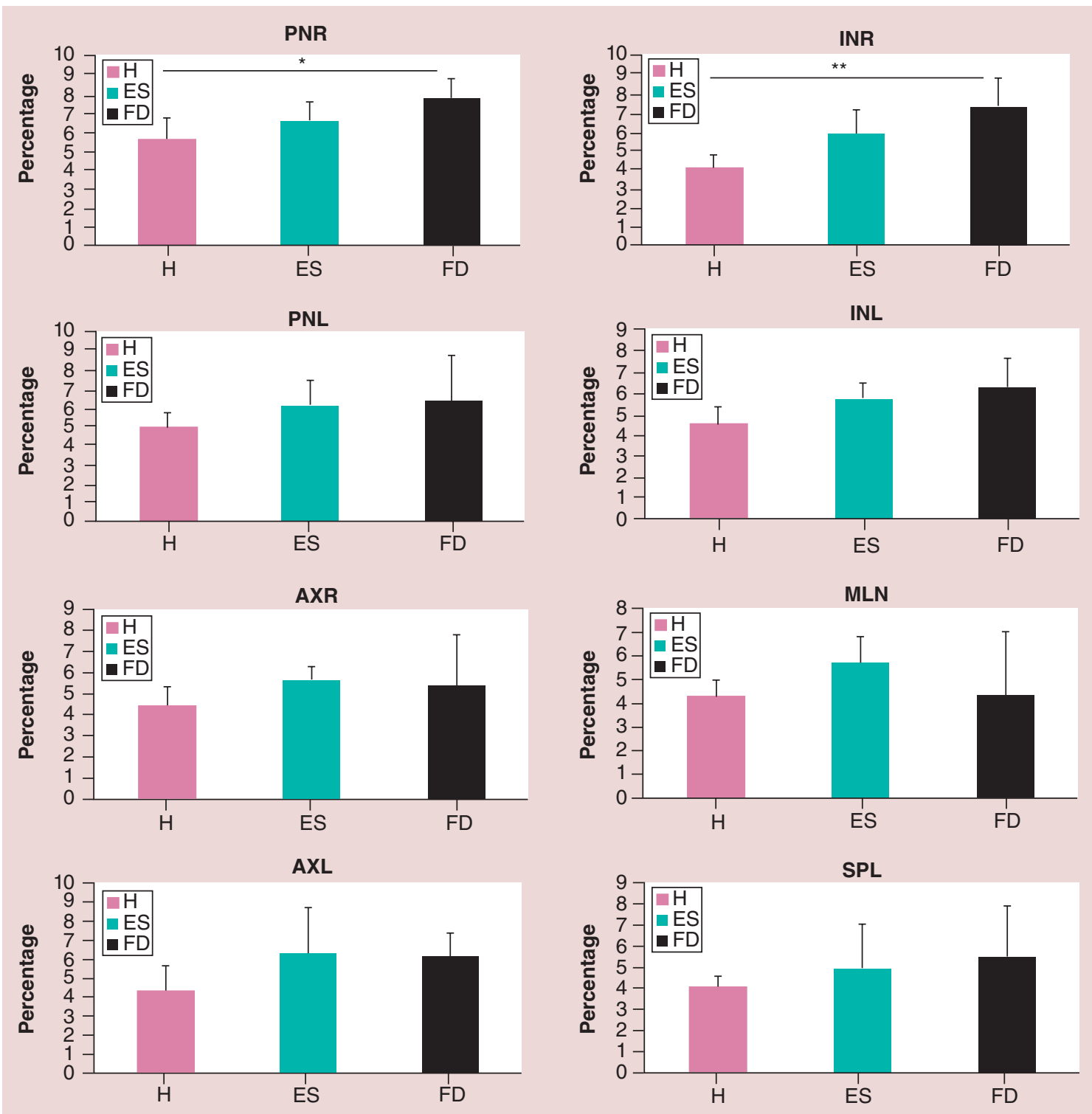

Figure 6. Percentage of $\mathrm{CD} 4{ }^{+} \mathrm{CD} 25^{+}{ }^{+} \mathrm{OXP3} 3^{+}$cells within the population of $\mathrm{CD} 4{ }^{+}$cells in rats with collageninduced arthritis 14 days after the adoptive transfer. Early-stage collagen-induced arthritis (CIA; group ES); fully developed CIA (group FD). $n=4$.

* Significant difference at $p<0.05$.

**Significant difference at $p<0.01$.

AXL: Left axillary lymph nodes; AXR: Right axillary lymph nodes; ES: Early stage; FD: Fully developed; H: Control; INL: Left inguinal lymph nodes; INR: Right inguinal lymph nodes; MLN: Mesenteric lymph nodes; PNL: Left popliteal lymph nodes; PNR: Right popliteal lymph nodes; SPL: Spleen.

of adoptively transferred Tregs in these lymph nodes was markedly decreased, when compared with healthy animals. Moreover, the frequency of migrated adaptive Tregs was higher in the ES group than in the FD group. Such differences indicate that the degree, to which the inflammatory process is advanced, is critical for directing immune cells toward lymphatic tissues.

Moreover, flow cytometric studies of the frequency of iTregs $\left(\mathrm{CD}^{+}{ }^{+} \mathrm{CD} 25^{+} \mathrm{FOXP}^{+}\right)$have shown a significantly higher percentage of these cells in the right popliteal and right inguinal lymph nodes in animals with fully developed CIA in comparison to healthy individuals. On the other hand, we observed a concomitant absence of adoptively transferred Tregs in these lymphatic structures. Nevertheless, this indicates that increased frequency of iTregs in lymphatic tissues, which control the inflamed area, is not equivalent to their suppressive functionality.

It is interesting that we did not observe the migration of adaptive Tregs into MN, neither the ES group 
nor the FD group, and in healthy animals the frequency of transferred cells in MLNs was lower than in the spleen. Similarly, Föhse et al. preferentially recovered adoptively transferred polled lymph nodes and spleen-derived Tregs from nongut lymph nodes [36]. Iwata $e t a l$. found in their research that migration of naive $\mathrm{CD}^{+}{ }^{+}$cells into the SI, PP and MN was induced by ATRA in in vitro culture conditions. They also found that ATRA-induced expression of $\alpha 4 \beta 7$ and CCR9 allows migration into SI, PP and MN [25]. In our unpublished research, we observed that in vitro stimulation by ATRA induces the migration of aTregs into the $\mathrm{MN}$ in rats from the ES group. These results confirmed that stimulation by ATRA is necessary to guide aTreg migration into $\mathrm{MN}$.

Migration and accumulation of adoptively transferred Tregs in organ-draining lymph node depend on their site of origin, state of activation and time passed from the moment of administration [13]. It has been previously described that Tregs isolated from draining lymph nodes could suppress autoimmune diseases: $0.03 \times 10^{6}$ Tregs isolated from ovarian lymph nodes of normal mice and transferred into thymectomized mice suppress autoimmune ovarian disease (AOD); $0.01 \times 10^{6}$ Tregs isolated from prostate lymph nodes of normal mice and transferred into thymectomized mice suppress experimental autoimmune prostatitis (EAP); $0.03 \times 10^{6}$ Tregs isolated from lacrimal gland lymph nodes of normal mouse and transferred into thymectomized mice suppress dacryloadenitis (DA). Tregs from nondraining LN, as opposed to those from draining LN, showed similar effect in suppression of AOD, EAP and DA, but $0.5 \times 10^{6}$ Tregs had to be transferred [24]. However, in our study we have observed that local injection of $0.2 \times 10^{6}$ lymphocytes isolated from spleen and from different lymph nodes of healthy animals and then polled, propagated and differentiated into Tregs suppressed CIA only in the early stage of disease. This indicates that the early stages of the disease are more susceptible to Treg suppression, even if they are not specific for the antigen and the proportion of cells derived from the organ-draining lymph node was considerably low.

RA is a chronic and progressive systemic immunemediated inflammatory disease that affects about $0.5-1.0 \%$ of adults in developed countries. According to the European League against Rheumatism 2013 recommendations, therapy should be started as soon as the diagnosis of RA is made and treatment should be aimed at remission or low disease activity in every patient [37]. Advances in the treatment of RA in the past decade have been achieved mainly by using combinations of different conventional and biologic disease- modifying antirheumatic drugs. Up to date, however, no final solution has been achieved. Despite the fact that therapy with biologics constitutes a breakthrough in RA management, still no improvement is achieved in approximately $30 \%$ of cases and another $20 \%$ of patients discontinue the therapy because of side effects. Thus novel approaches are urgently needed [38] and among them adoptive transfer of Tregs is one of the considered solutions in the treatment and prevention of RA.

\section{Conclusion}

Our work has shown that cell culture of $\mathrm{CD} 4^{+} \mathrm{CD} 25^{+}$ with $17-\beta$-estradiol is a suitable solution for obtaining iTregs for adoptive transfer. The success of this potential immunomodulatory therapy depends on the disease progress and is related to different patterns of migration of adaptive Tregs to local, especially popliteal and inguinal lymph nodes. Intra-articular injection of iTregs ameliorates symptoms of CIA. However, individual-specific variation in response to treatment and disease stage dependence was observed. Worth noting is the fact that migration of aTregs and peripheral iTregs is differently regulated under inflammatory than in normal conditions.

\section{Future perspective}

Nowadays many research articles are focused on testing of immunomodulatory therapies based on adoptive transfer of Tregs. Our results have shown that this type of treatment is possible but it depends on progression of the disease. With this knowledge and more information about mechanisms of regulatory function of Treg in autoimmune diseases coming to light in the next 5-10 years it will be possible to use Tregs as a therapy tool in heal autoimmune diseases.

\section{Authors' contributions}

I Felcenloben: $50 \%$ study conception, 50\% study design, induction of $\mathrm{CIA}$, data collection of $70 \%$ clinical assessment of CIA symptoms, 100\% ELISA test, 30\% FACS sorting, 80\% FACS analysis, cell culture, 50\% adoptive transfer, CellTracker staining, and interpretation of data, $70 \%$ manuscript drafting. T Piasecki: $100 \%$ data collection of $x$-ray, 50\% interpretation of data of $x$-rays. J Miller: data collection of $20 \%$ clinical assessment of CIA symptoms, 10\% FACS analysis, and preparing hind paws for $x$-ray and histological analysis. J Rossowska: data collection of $70 \%$ FACS sorting and interpretation of data. $E$ Bańcyr: data collection of $10 \%$ clinical assessment of CIA symptoms, 10\% FACS analysis. W Atamaniuk: 50\% x-ray analysis and $50 \%$ interpretation of data of $\mathrm{x}$-rays. M Nowak: histological analysis and interpretation of data. J Świerkot: critical revision of the manuscript, 5\% manuscript drafting. K Ratajczak: 10\% study design, 50\% adoptive transfer. A Chełmońska-Soyta: 
$50 \%$ study conception, $40 \%$ study design, $25 \%$ manuscript drafting and critical revision of the manuscript. All authors read and approved the final manuscript.

\section{Acknowledgements}

The authors acknowledge L Ignatowicz and M Kuczma from the Medical College of Georgia, Center for Biotechnology \& Genomic Medicine, Augusta, GA, USA, and Y Shoenfeld from Sheba Medical Center at Tel Hashomer in Israel, who critically reviewed the results and proposed a new approach for the project, and R Miedzybrodzki from Ludwik Hirszfeld Institute of Immunology and Experimental Therapy, Polish Academy of Sciences for permission for the algorithm of developmental assessment of $\mathrm{CIA}$.

\section{Financial \& competing interests disclosure}

This work was supported by Project N N308 628238 and co-financed by the Ministry of Science and Higher Education in Poland, by the European Union as part of the European Social Fund, and the project is supported by Wroclaw Centre of Biotechnology program at The Leading National Research Centre (KNOW) from 2014 to 2018. The authors have no other relevant affiliations or financial involvement with any organization or entity with a financial interest in or financial conflict with the subject matter or materials discussed in the manuscript apart from those disclosed.

No writing assistance was utilized in the production of this manuscript.

\section{Ethical conduct of research}

The authors state that they have obtained appropriate institutional review board approval or have followed the principles outlined in the Declaration of Helsinki for all human or animal experimental investigations. In addition, for investigations involving human subjects, informed consent has been obtained from the participants involved.

\section{Executive summary}

- In in vitro conditions, $17-\beta$-estradiol is a good inducer of Foxp3 in CD4+CD25+ cells. In our research expression of Foxp3 was higher in the presence of $10 \mathrm{ng} / \mathrm{ml} 17-\beta$-estradiol.

- Local injection of lymphocytes isolated from the spleen and from different lymph nodes of healthy animals and then pooled, propagated and differentiated into Tregs suppressed collagen-induced arthritis only in the early stage of disease.

- Migration of adaptive Tregs and peripheral, physiologically occurring Tregs is differentially regulated in collagen-induced arthritis and normal conditions.

- Success of this potential immunomodulatory therapy depends on the disease progress and it is related to different migration of adaptive Tregs to local lymph nodes, especially into popliteal and inguinal lymph nodes.

\section{References}

1 Sakaguchi S, Fukuma K, Kuribayashi K et al. Organ-specific autoimmune diseases induced in mice by elimination of T cell subset. I. Evidence for the active participation of $\mathrm{T}$ cells in natural self-tolerance; deficit of a $\mathrm{T}$ cell subset as a possible cause of autoimmune disease. J. Exp. Med. 161(1), 72-87 (1985).

2 Hori S, Nomura T, Sakaguchi S. Control of regulatory T cell development by the transcription factor Foxp3. Science 299(5609), 1057-1061 (2003).

3 McHugh RS., Whitters MJ, Piccirillo CA et al. CD4+ CD25+ immunoregulatory $\mathrm{T}$ cells: gene expression analysis reveals a functional role for the glucocorticoid-induced TNF receptor. Immunity 16(2), 311-323 (2002).

4 WING K, Onishi Y, Prieto-Martin P et al. CTLA-4 control over Foxp $3^{+}$regulatory T cell function. Science 322(5899), 271-275 (2008).

5 de La Rosa M, Rutz S, Dorninger $\mathrm{H}$ et al. Interleukin-2 is essential for $\mathrm{CD}^{+} \mathrm{CD} 25^{+}$regulatory T cell function. Eur. J. Immunol. 34(9), 2480-2488 (2004).

6 Bolzer K, Käser T, Saalmüller A et al. Molecular characterisation of porcine Forkhead-box p3 (Foxp3). Vet. Immunol. Immunop. 132(2), 275-281 (2009).

7 Hori S. Developmental plasticity of Foxp $3^{+}$regulatory T cells. Curr. Opin. Immunol. 22(5), 575-582 (2010).
8 Kresina TF, Moskowitz RW. Adoptive transfer of suppression of arthritis in the mouse model of collagen-induced arthritis. Evidence for a type II collagen-specific suppressor T cell. J. Clin. Invest. 75(6), 1990-1998 (1985).

9 Sakaguchi S, Sakaguchi N, Asano M et al. Immunologic self-tolerance maintained by activated $\mathrm{T}$ cells expressing IL-2 receptor alpha-chains (CD25). AAI 155, 1151-1164 (1995).

10 Morgan ME, Flierman R, van Duivenvoorde LM et al. Effective treatment of collagen-induced arthritis by adoptive transfer of CD $25^{+}$regulatory T cells. Arthritis Rheum. 52(7), 2212-2221 (2005).

11 Kohm AP, Carpentier PA, Anger HA et al. Cutting edge: $\mathrm{CD} 4{ }^{+} \mathrm{CD} 25^{+}$regulatory $\mathrm{T}$ cells suppress antigen-specific autoreactive immune responses and central nervous system inflammation during active experimental autoimmune encephalomyelitis. J. Immunol. 169(9), 4712-4716 (2002).

12 Mukherjee R, Chaturvedi P, Qin HY et al. CD $4^{+} \mathrm{CD} 25^{+}$ regulatory $T$ cells generated in response to insulin $\mathrm{B}: 9-23$ peptide prevent adoptive transfer of diabetes by diabetogenic T cells. J. Autoimmun. 21(3), 221-237 (2003).

13 Whitacre CC, Reingold SC, O'Looney PA. A gender gap in autoimmunity. Science 283(5406), 1277-1278 (1999).

14 La Rocca C, Carbone F, Longobardi S et al. The immunology of pregnancy: Regulatory $\mathrm{T}$ cells control maternal immune tolerance toward the fetus. Immunol. Lett. 162(1), 41-48 (2014). 
15 Nelson LR, Bulun SE. Estrogen production and action. J. Am. Acad. Dermatol. 45 (3 Suppl.), S116-S124 (2001).

16 Tai P, Wang J, Jin $\mathrm{H}$ et al. Induction of regulatory $\mathrm{T}$ cells by physiological level estrogen. J. Cell Physiol. 214(2), 456-464 (2008).

$17 \mathrm{Lu} \mathrm{L}, \mathrm{Li} \mathrm{G}$, Rao J et al. In vitro induced $\mathrm{CD} 4\left(^{+}\right) \mathrm{CD} 25\left(^{+}\right)$ Foxp $3\left(^{+}\right)$Tregs attenuate hepatic ischemia-reperfusion injury. Int. Immunopharmacol. 9(5), 549-552 (2009).

18 Mucida D, Pino-Lagos K, Kim G et al. Retinoic acid can directly promote TGF- $\beta$-mediated Foxp $3^{+}$Tregs cell conversion of naive T cells. Immunity 30 (4), 471-472 (2009).

19 Mucida D, Park Y, Cheroutre H. From the diet to the nucleus: vitamin A and TGF- $\beta$ join efforts at the mucosal interface of the intestine. Semin. Immunol. 21(1), 14-21 (2009).

20 Maj T, Switała-Jelen K, Miazek A et al. Effects of tamoxifen on estrogen receptor- $\alpha$ level in immune cells and humoral specific response after immunization of $\mathrm{C} 3 \mathrm{H} / \mathrm{He}$ male mice with syngeneic testicular germ cells (TGC). Autoimmunity 44(6), 520-530 (2011).

21 von Boehmer H. Oral tolerance: is it all retinoic acid? J. Exp. Med. 204(8), 1737-1739 (2007).

22 Luo CY, Wang L, Sun C et al. Estrogen enhances the functions of $\mathrm{CD} 4{ }^{+} \mathrm{CD} 25^{+} \mathrm{Foxp}^{+}$regulatory $\mathrm{T}$ cells that suppress osteoclast differentiation and bone resorption in vitro. Cell Mol. Immunol. 8(1), 50-58 (2011).

23 Lieberman SM, Kim JS, Corbo-Rodgers E et al. Site-specific accumulation of recently activated $\mathrm{CD}^{+}{ }^{+} \mathrm{FOXP}^{+}$regulatory T cells following adoptive transfer. Eur. J. Immunol. 42(6), 1429-1435 (2012).

24 Wheeler KM, Samy ET, Tung KS. Cutting edge: normal regional lymph node enrichment of antigen-specific regulatory $\mathrm{T}$ cells with autoimmune disease-suppressive capacity. J. Immunol. 183(12), 7635-7638 (2009).

25 Iwata M, Hirakiyama A, Eshima $Y$ et al. Retinoic acid imprints gut-homing specificity on T cells. Immunity 21(4), 527-538 (2004).

26 Suszko A, Obmińska-Mrukowicz B. Influence of polysaccharide fractions isolated from Caltha palustris L. on the cellular immune response in collagen-induced arthritis (CIA) in mice. A comparison with methotrexate. J. Ethnopharmacol. 145(1), 109-117 (2013).
27 Polanczyk MJ, Carson BD, Subramanian S et al. Cutting edge: estrogen drives expansion of the $\mathrm{CD}_{4}{ }^{+} \mathrm{CD} 25^{+}$ regulatory T cell compartment. J. Immunol. 173(4), 2227-2230 (2004).

28 Ohata J, Miura T, Johnson TA et al. Enhanced efficacy of regulatory $\mathrm{T}$ cell transfer against increasing resistance, by elevated FOXP3 expression induced in arthritic murine hosts. Arthritis Rheum. 56(9), 2947-2956 (2007).

29 Morgan ME, Sutmuller RP, Witteveen $\mathrm{HJ}$ et al. $\mathrm{CD} 25^{+}$cell depletion hastens the onset of severe disease in collageninduced arthritis. Arthritis Rheum. 48(5), 1452-1460 (2003).

30 Charbonnier LM, Han WG, Quentin J et al. Adoptive transfer of IL-10-secreting $\mathrm{CD} 4{ }^{+} \mathrm{CD} 49 \mathrm{~b}^{+}$regulatory $\mathrm{T}$ cells suppresses ongoing arthritis. J. Autoimmun. 34(4), 390-399 (2010).

31 Kwok SK, Park MK, Cho ML et al. Retinoic acid attenuates rheumatoid inflammation in mice. J. Immunol. 189(2), 1062-1071 (2012).

32 Komatsu N, Okamoto K, Sawa S et al. Pathogenic conversion of FOXP3 ${ }^{+} \mathrm{T}$ cells into TH17 cells in autoimmune arthritis. Nat. Med. 20(1), 62-68 (2014).

33 Emery P, Breedveld FC, Dougados M et al. Early referral recommendation for newly diagnosed rheumatoid arthritis: evidence based development of a clinical guide. Ann. Rheum. Dis. 61(4), 290-297 (2002).

34 Offner H. Neuroimmunoprotective effects of estrogen and derivatives in experimental autoimmune encephalomyelitis: therapeutic implications for multiple sclerosis. J. Neurosci. Res. 78, 603-624 (2004).

35 Offner H, Polanczyk M. A potential role for estrogen in experimental autoimmune encephalomyelitis and multiple sclerosis. Ann. NY Acad. Sci. USA 1089, 343-372 (2006).

36 Föhse L, Suffner J, Suhre K et al. High TCR diversity ensures optimal function and homeostasis of FOXP $3^{+}$regulatory T cells. Eur. J. Immunol. 41(11), 3101-3113 (2011).

37 Brühl H, Cihak J, Schneider MA et al. Dual role of CCR2 during initiation and progression of collagen-induced arthritis: evidence for regulatory activity of CCR2 $\mathrm{T}$ cells. J. Immunol. 172, 890-898 (2004).

38 Feist E, Burmester G. Small molecules targeting JAKs - a new approach in the treatment of rheumatoid arthritis. Rheumatology 52, 1352-1135 (2013). 